\title{
Določila za razvrščanje podobno in enako pisanih iztočnic v slovarskem delu novega Slovenskega pravopisa
}

\author{
Peter Weiss
}

IZVLEČEK: V prispevku so najprej obravnavani načini abecednega razvrščanja in načini razvrščanja podobno in enako pisanih iztočnic $v$ slovenskih slovarskih in enciklopedičnih (ali leksikonskih) delih. Za slovarski del nastajajočega Slovenskega pravopisa so predlagana določila, ki omogočajo enotno razvrščanje podobno in enako pisanih iztočnic ter rabo indeksov pri iztočnicah $z$ enakimi značilnostmi (pisna podoba, naglas, besednovrstni podatek, spol in podatek o neprvi osnovni slovarski obliki).

\begin{abstract}
The principles which Slovenian dictionaries and encyclopedias (lexicons) use in alphabetization and ordering of main entries having similar or homonymous spellings are discussed in the first part of the article. For the dictionary part of the new Slovenian Orthographic Code guidelines are suggested for uniform ordering of main entries with similar or homonymous spelling, and the use of index numbers for main entries sharing equal features (spelling, stress, information on word class, gender and the first inflected form to be included in the dictionary).
\end{abstract}

\section{A}

Pri izdelavi slovarskih in tudi enciklopedičnih (ali leksikonskih) del se je treba odločiti za zaporedje iztočnic, ki je v njih največkrat abecedno, ker je optimalno (Zgusta 1991: 265), seveda pa je lahko tudi drugačno, npr. v slikovnih ali tematskih slovarjih, $\mathrm{v}$ katerih pa so po navadi abecedno urejeni priloženi seznami besed (indeksi, registri). Nemško-slovenski slikovni slovar 1987 ima dodan abecedno urejeni nemški in slovenski seznam, medtem ko je v Angleško-slovenskem slikovnem slovarju (Parnwell 1986) sicer dodan abecedno urejeni angleški seznam, kljub naslovu pa so slovenski v njem le prevodi angleških izrazov na posameznih ilustriranih straneh. V slovarju govora Gozda Martuljka in Srednje vasi Stanka Koširja (Košir 1997) je na primer besedno gradivo urejeno načeloma po besednih vrstah in pri posameznih besednih vrstah abecedno $\mathrm{z}$ upoštevanjem posebnih znakov; marsikdaj samovoljno urejeni narečni slovar nima priloženega abecednega seznama (prim. Weiss 1998: 195).

Pri abecednem razvrščanju glede osnovne abecede v slovenskem jeziku sko- 
rajda ni težav: posebnosti ob 25 črkah, ki sestavljajo slovensko abecedo, so črke $q$ (ta stoji za $p$ ), $w, x$ in $y$ (te stojijo med $v$ in $z$ ) ter $c$, ki stoji za $\check{c}$, in $\not$, ki stoji za $d$ (SP 1997: § 6). Pri $c$ in $d$ torej ne velja pravilo, da »črke z ločevalnimi znamenji (npr. $a$ $q \ddot{u} \phi \zeta \tilde{n} k$ ) [..] po abecedi uvrščamo, kot da ne bi imele teh znamenj« (SP 1997: $\S$ 6). Če za ti dve črki ne bi veljala izjema, bi bil $c$ položajno izenačen $\mathrm{s} c$ in $d \mathrm{z} d$, čeprav bi goli $c$ in $d$ še vedno imela prednost; tako bi bilo zaporedje npr.:

Cosgrave

Ćosić

Cosimo

ali

\section{Jugovic}

Jugović

Jugovič

$\mathrm{Na}$ dva načina se že zdaj obnaša npr. črka $\dot{z}$ : poljski priimek Żeromski [žerómski], ki bi ga bilo treba abecedno uvrstiti pod $z$, v slovenskih enciklopedičnih in slovarskih priročnikih praviloma najdemo pod ž. Tako npr. v leksikonu Svetovna književnost iz leta 1984 priimka Żelenski in Żeromski stojita med priimkoma Zweig in Žukovski; geslo Żeromski stoji v LCZ iz leta 1994 med gesloma žerka in žgalna dlačica, v VSL iz leta 1998 pa med gesloma žerka in žeruh.

$\mathrm{V}$ abecedah različnih jezikov in tudi v črkopisih, ki so bili v rabi v slovenščini v posameznih obdobjih, so posebnosti glede na (današnjo knjižno) slovenščino pri abecednem razvrščanju lahko prav velike. Digraf $c h$ se v nemščini obravnava, kot da gre za črki $c$ in $h$, v češčini pa kot monograf, katerega mesto v češki abecedi je za $h$ in pred $i$ (Zgusta 1991: 265). Na koncu švedske abecede črki $z$ sledijo črke $a ̊ a$ in $\ddot{o}$, kar kaže, da univerzalno abecedno zaporedje za vse jezike, čeprav bi bilo zelo priročno, ni možno. Posebni so s tega stališča tudi različni slovenski črkopisi (različice bohoričice ter metelčica in dajnčica), pri katerih lahko napačno razumevanje abecednega zaporedja povzroči celo napačne zaključke. (Za abecedno zaporedje v slovensko-nemškem slovarju Antona Murka iz leta 1832 prim. Weiss 1999: 211, točka 1.6.)

Pri abecednem zaporedju iztočnic (tudi v golih abecednih seznamih) se pojavi prva težava pri razvrščanju večbesednih iztočnic, pri katerih se presledek (a) zanemari (razvrščanje po črkah, angl. letter-by-letter - manj jasen je izraz absolutna abeceda, ki ga je prav tako mogoče srečati, npr. v ES 6: XI s ponazorilom $B O J E V N I K$ :: BOJ ZA MEJE) ali pa se (b) upošteva kot poseben znak, ki se razvršča, kot da bi stal na začetku abecede (razvrščanje po besedah, angl. word-by-word) (Landau 1991: 82-83; Svensén 1993: 223-224). Status posebnega znaka, kakršnega ima presledek, lahko ima tudi kak drug znak, npr. opuščaj, kot v obrnjenem Gutsmanovem slovarju, ki ga je pripravil Ludvik Karničar (Karničar 1999). (Prim. ES 6: XI: »Morebitna ločila (vejica, vezaj, okrogli oklepaj, opučaj) in druge pisne posebnosti v geselski besedi ne vplivajo na abecedni red.«) To niti ni slaba rešitev, saj bi bile iztočnice $\mathrm{z}$ začetno sestavino $v^{\prime}$.. sicer pomešane med vse druge, ki se začnejo $s$ črko $v$. (Vendar pa je tu prišlo še do neustreznega (računalniškega?) ločevanja polkrepkega in navadnega tiska, kar vpliva na abecedno razvrstitev. Pri pred$\operatorname{logih} v^{\prime}, k^{\prime}$ in $z^{\prime}$ polkrepkim iztočnicam (s takim tiskom je označeno Gutsmanovo 
zaporedje sestavin) od v'bieg do v'žoudjemati, sledijo navadno tiskane (kar opozarja na to, da jih je obrnil urednik) od v'briezni do v'zaton, pri tem pa samo navadno natisnjena iztočnica $v$ 'žlahti stoji na abecedno ustreznem mestu med polkrepkimi (Karničar 1999: 615-617; prim. Weiss 199a).

V slovenskem knjižnem slovaropisju se je uveljavilo razvrščanje po črkah (SSKJ, LCZ, VSL), predvsem v golih abecednih seznamih pa je zelo uveljavljeno razvrščanje po besedah. Tako so različno razvrščene tele iztočnice, napaberkovane iz SSKJ-ja. V SSKJ-ju je dalo razvrščanje po črkah zaporedje, kot je predstavljeno tule v stolpcu A (edino à la in ala sta razvrščena v nasprotju s siceršnjim pravilom), iste iztočnice pa bi bile $\mathrm{z}$ razvrščanjem po besedah razporejene precej drugače, tako kot je navedeno tule v stolpcu B:

A: razvrstitev po črkah
a
abak
abuzus
a capella
accelerando
ačih
ad
ad acta
adagio
ad infinitum
akviziterski
à la
ala
alabaster
à la carte
alarm
alfa
alfabetski
alfa romeo
al fresco
alga
alimentirati
a limine
aktiven
averzija
a vista

B: razvrstitev po besedah

a

a capella

à la

à la carte

a limine

a vista

abak

abuzus

accelerando

ačih

ad

ad acta

ad infinitum

adagio

aktiven

akviziterski

al fresco

ala

alabaster

alarm

alfa

alfa romeo

alfabetski

alga

alimentirati

averzija

Iztočnice so razvrščene po besedah npr. v slovenskem seznamu v Nemškoslovenskem slikovnem slovarju 1987, kjer se srečamo tudi s težavno določitvijo, kaj pravzaprav sploh je iztočnica, saj so tu iztočnice praviloma enobesedne in za njimi, če jim je dodana še kaka sestavina, največkrat stoji vejica, pa najsi je to potrebno ali ne: v strelec, cirkuški je vejica potrebna, saj gre za zamenjavo sestavin, medtem ko je v primerih strel, iz kota ali streljanje, kleče ali stresalo, pretresalne verige odveč; vejice ni recimo v primeru strežba kave v kavarni, kar je seveda prav (Nemško-slovenski slikovni slovar 1987: 835). Iztočnica (pravzaprav začetna bese- 
da) je v primeru, ko bi se ista pojavila drugič, tretjič itd., nadomeščena s pomišljajem pred dodano sestavino. V geslu stožec je zaporedje dodanih sestavin vulkanski :: z mlevnimi noži :: z ogljikovimi vlakni okrepljen nosni :: zavorni, kar kaže, da so v seznamu iztočnice (pravzaprav podiztočnice) abecedno razvrščene po besedah. Gesla so razvrščena po besedah tudi v seznamu zemljepisnih imen na Turistični avtokarti Slovenije iz leta 1999 in v Atlasu Slovenije iz leta 1985, kjer se kot poseben znak, ki vpliva na abecedno razvrstitev, šteje tudi pika; tako si npr. sledijo: Sužiška planina :: Sv. Križ (popolnoma nejasno, zakaj je tu) :: Sv. Ana :: [..] :: Sv. Volbenk :: Sv.Ana :: Sv.Andrej :: Sv.Avguštin $::$ Sv.Katarina (v zadnjih štirih primerih ni presledka, kar spet vpliva na abecedno razvrstitev) :: Svačica (AS 1985: 354). Podobno so razvrščena tudi gesla v Telefonskem imeniku Slovenije 1998: $D D C::$ DE BREA :: DE CECCO :: DE CORTTI :: [..] :: DE ZORDO :: DEAN :: DEANKOVIC (TIS 1998 1: 65). Tovrstna razvrstitev (po besedah) zahteva od uporabnika po svoje večji napor kot razvrstitev po črkah, saj mora iskalec podatka recimo v telefonskem imeniku natančno vedeti, kako se piše ime, ki ga išče, npr. s presledkom ali brez njega (to lahko zelo moti pri iskanju v računalniški obliki, v kakršni je dostopen telefonski imenik, seveda pa je kdaj zaradi razlikovalnosti lahko tudi v pomoč), poleg tega pa je v računalniškem programu, s katerim so bile iztočnice v TIS 1998 razvrščene po abecedi, še nekaj pasti in nejasnosti, saj šteje za črkovne znake poleg presledka tudi števke, ločila in simbole, le da ni nikjer razloženo, v kakšnem zaporedju. Tako povsem na začetku seznama telefonskih naročnikov na področju Ljubljane najdemo imena $\mathrm{v}$ takemle zaporedju:

$\mathrm{A}+3$

A \& B AGENCIJA

[..]

A \& O SISTEMI

A ATLANTA

A FORM

A INŽENIRING

A 2

A 3

A.A. BUSINESS CENTER

A.A.L. ALPE ADRIA LEASING

[..]

A.V.T.

A - COSMOS

A - FINIS

A - MARKETING

A - PERFECT

A-TRADE

A-Z FINANCE

A - Ž CONSULTING

AA \& SARA

AA BUSINESS CENTER

[..]

AA TRADE BIO 92 


\section{AA - ANONIMNI ALKOHOLIKI}

AANIMA

AARON [ki je v tem zaporedju prvi priimek] (TIS 1998 1: 15)

Računalniški program bi moral pri razvrščanju po črkah presledek, ločila in simbole praviloma zanemariti in številke postaviti pred črko $a$, medtem ko so pri razvrščanju po besedah pravila manj jasna. (Tako ima TIS 2000, ki ima v primerjavi s TIS 1998 pri abecednem razvrščanju nekaj prav slabih rešitev, še pred začetkom črke A rubrične naslove 1 (od $1 M A H$ do 14 ), 2 (od $2 M$ do $2 B$ ), 3 (od 3-TEC do 3TRADE), 4 (4M), 7 (7 TRADE) - TIS 2000: 13.) Sicer pa je za TIS 1998 pretežka že črka $\dot{c}$, saj stoji takoj za $c$ in pred $\check{c}$, tako da je v njem zaporedje res JUGOVIC:: JUGOVIC-KOFOL :: JUGOVIĆ :: JUGOVIĆ-KRALJ in JUGOVIČ (TIS 1998 1: 137). TIS 2000 te napake nima več, črka $đ$ pa stoji v obeh izdajah telefonskega na ustreznem mestu, takoj za črko $d$ (prim. Weiss 1999b).

V TIS 1998 je ustrezno tudi zaporedje priimkov KUHAR (od Ivan do Vojko) in KÜHAR (Stanislav), čemur sledi priimek KUHAR-MEVŽELJ(TIS 1998 1: 172). Herbert Ernst Wiegand (1989: 377-378) se boji, da bi lahko formulacija, ki jo je mogoče najti v nemških slovarjih, namreč da so črke s preglasi razvrščene kot črke brez preglasov, botrovalo zaporedju $\mathrm{Bar}^{1}:: \mathrm{Bär}:: \mathrm{Bar}^{2}$. Neustrezno ravna ES 6: 6465, ki ima zaporedje KUHAR, Alojzij :: KUHAR, Boris :: KUHAR, Janez :: KÜHAR, János :: KUHAR, Lovro. V TIS 2000 je zaporedje priimkov in njihovih različic še bolj nenavadno, že kar nepregledno: KUHAR-MEVŽELJ :: KUHAR-REŽEK :: KUHAR-ZAJEC :: KUHAR (od Amalija do Silva) :: KÜHAR (Stanislav) :: spet KUHAR (od Štefan do Vojko) :: KUHARIČ-MAHKOVEC :: KUHARIČ (od Aleksander do Neva). Dvojni priimki seveda morajo stati za enojnimi - rešitev v TIS 1998 je bila glede tega povsem ustrezna -, pa tudi zaporedja MÜLLER, od Aco do Andreja, nikakor ne bi smel prekiniti primer MULLER (Blažka - tu gre pri priimku skoraj gotovo za pomoto), kateremu potem sledi zaporedje $M \ddot{U} L L E R$, in sicer od Bogdan do Zvonka (prim. Weiss 1999b).

Abecedno razvrščanje v narečnih slovarjih, ki nimajo poknjiženih iztočnic, je lahko precej nepregledno in tudi samovoljno (gl. Novak 1996: geslu bùša sledi geslo büditi, kar kaže, da se črka $\ddot{u}$ šteje za posebno črko, ki se abecedno uvršča za $u$; prim. Kenda-Jež - Weiss 1999: 33-36; Weiss 1998a: 191). Tudi poskusni snopič Slovarja stare knjižne prekmurščine ima pri abecednem razvrščanju glede na normativne priročnike slovenskega knjižnega jezika posebnosti, kakršne so že v Slovarju beltinskega prekmurskega govora Franca (in Vilka) Novaka, vendar so razvidne le iz gradiva, saj ni nikjer navedeno abecedno zaporedje uporabljenih črk; tako npr. $d$ ' stoji za $d$-geslu $d v o r$ sledi geslo d'am - in $\ddot{u}$ za $u$-geslu mujvalnica sledi geslo müdba (Novak 1988: 19).

Danes, ko gesla po abecedi v slovarskih in enciklopedičnih delih namesto človeka veliko hitreje in učinkoviteje razvrsti računalnik, je seveda težko uvajati izjeme, kakršna je v angleških slovarskih in enciklopedičnih delih recimo pri pred-

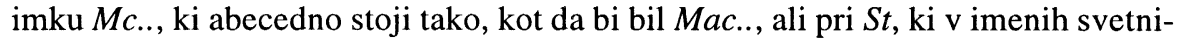
kov in v zemljepisnih imenih pomeni Saint in ga nekateri slovarji postavljajo na to mesto (za to dvoje gl. Webster 1980: 10a; pravilo velja glede $M c$.. tudi v Longman 
1992, v katerem pa je recimo v geslu Saint Bernard mogoče najti kazalko k $S t$ Bernard), in glede upoštevanja nepolnopomenskih besed pri abecednem razvršča$\mathrm{nju}(\mathrm{v}$ angleški zvezi accessory sinuses of the nose se of in the pri abecednem razvrščanju ne upoštevata - Landau 1991: 82-83). Tudi razvrščanje nemških črk s preglasi, npr. $\ddot{o}$ kot $o e$, je čudaško (prim. Metzler Lexikon Sprache 1993: 434: Occidental-Interlingue :: Öffnungslaut :: [..] :: Ötzbekisch :: Offen).

Vendar pa bo vsakdanja praksa še naprej stregla $\mathrm{z}$ nečrkovnimi primeri, ki jih bo treba uvrščati v slovarje, enciklopedije in leksikone ter raznovrstne abecedne sezname. Tako je naslov revije 2000 priporočljivo uvrstiti po abecedi na mesto, kjer bi se nahajal s črkami izpisani naslov (tako ravnajo tudi bibliografi), namreč $d v a$ tisoč, kar je v natančnejših slovarjih tako zapisano tudi kot izgovor tega imena. Naslov 1551 je mogoče brati na dva načina, kot tisoč petsto enainpetdeset ali kot petnajststo enainpetdeset - v Enciklopediji Slovenije je za zdaj na tem mestu le kazalčno geslo (z naslovom, ki je v oglatem oklepaju zapisan $\mathrm{z}$ besedami), ki kaže na (bolj uveljavljeni izgovor) tisoč petsto enainpetdeset, kjer bo predstavljeno celotno geslo (ES 8: 327; toda prim. omejitev na str. XII: »Gesla so razporejena po absolutni slovenski $\rightarrow$ abecedi zapisa (ne izgovora) geselskih besed «). Podobno težavo predstavljajo še npr. imena $7 D$ |revijal, $V-1, V-2$ |orožje|, $B-52$ |bombnik|. Po enem pravilu se številke pri abecednem razvrščanju zanemarijo, čeprav se v enciklopedičnih delih upoštevajo pri imenih vladarjev, ki imajo dodane identifikacijske rimske številke (Landau 1991: 84 ima zaporedje $H g:: h G:: H G:: h \mathrm{G}:: \operatorname{lhg}:: h g 1$ $:: h g^{-1}:: h g_{\infty}$ itd.), vendar potem sploh ni mogoče upoštevati imen 1551 ali 2000 , po drugem se števke in številke upoštevajo, kot da bi se izpisovale $\mathrm{z}$ besedami, po tretjem se abecedno razvršča, kot da bi se izpisoval z besedo/črko, le številčni del, ki stoji pred črkovnim delom ( $7 D$ bi npr. stal na mestu pod sedem $D$ ), medtem ko se tisto, kar stoji na koncu (ali vmes), razvršča po velikosti, torej od $I:: 2:: 3$ ali od $I$ :: II :: III ali od $I$. :: II. :: III. naprej. (Računalnik lahko sicer števila razvršča kot besede (v zaporedju $1:: 12:: 123:: 2$ :: $21:: 213:: 3$ - Muren 1989: 184) ali pa po (naraščajoči ali padajoči) velikosti, torej $1:: 2$ :: 3 :: 12 :: 21 : 123 :: 213.) V specialnih, recimo terminoloških slovarjih se po abecedi in z upoštevanjem nadaljnjih določil razvrščajo še simboli, npr. $\mathrm{H}_{2} \mathrm{O}$ (Wiegand 1989: 375; Koblischke 1983: 8), vendar glede tega še nimamo ustreznih izsledkov, do katerih lahko pripelje le izdelovanje dovolj natančnih terminoloških slovarjev (prim. Gjurin 1986: 157: »Kam npr. uvrstiti - pri abecedni površčenosti gesel - arabske, kam rimske številke, kakšna je hierarhija med alografi iste črke (a, a, $\mathrm{A}, A$...), kako obravnavati indekse $\left(\mathrm{H}_{\mathrm{S}}\right.$, $\left.\mathrm{K}^{-1}, \mathrm{H}_{2} \mathrm{O},{ }^{\circ} \mathrm{C} \ldots\right)$..) $)$. V besedotvorni ali morfemski slovar so uvrščene npr. ničte končnice $(-\phi)$, ki v ustreznih ruskih slovarjih stojijo pred $a$, torej dejansko na samem začetku abecede (Kuznjecova - Jefremova 1986: 579). Vendar pa v druge enojezične slovarje taki podatki ne spadajo, saj jih je težko razvrščati na mesta, kjer jih bo uporabnik našel. (Prim. Toporišič 1994:461:»V slovarju bo [neglasovni (ničti) morfem - P. W.] zapisan za črko Ž [..].«) Zato je najbrž najbolje, da pridejo v posebne sezname $\mathrm{v}$ dodatke, povsem na konec abecednega zaporedja (kot ravna npr. Koblischke 1983: 471-504).

V slovenščini se nam v razvrščanje po abecedi poleg (1) osnovnih črk ( $a, b$ $\ldots z, \check{z}$ ) ponujajo še (2) dodatne črke, ki so (a) onaglašene, pri katerih je naglas (aa) 
obvezna sestavina (npr. v čeških, francoskih in španskih besedah ó) ali pa (ab) fakultativna (npr. $v$ onaglašenih iztočnicah $-\mathrm{v}$ slovenskih besedah po navadi naglasa ne pišemo, vendar pa je obvezen, ko je uveden, npr. v jezikoslovni rabi), (b) preglasne ipd. črke (ii), in (c) črkam komajda še podobni znaki $(\beta, @, \Omega, p, \$)$ ter (3) zunajabecedni znaki (številke, npr. v $\mathrm{H}_{2} \mathrm{O}$, ipd.) (po Wiegandu 1989: 374-375).

B

Pri razvrščanju iztočnic za slovar ali enciklopedično delo se pojavi težava, kako razvrstiti več podobno ali enako pisanih iztočnic (najmanj dve), ki so razvrščene abecedno, pa najsi bo odsprednje ali odzadnje, kot so na primer v OSSJ-ju. Pri delih manjšega obsega je tovrstnih zadreg malo, kopičiti pa se začnejo pri slovarskih in enciklopedičnih delih srednjega obsega, kakršno je SSKJ. Zato so v uvodu k SSKJ-ju, ki je slovar srednjega obsega, navedena sorazmerno natančna navodila za razvrščanje podobno in enako pisanih iztočnic (SSKJ 1: § 7-18), kjer pa vendarle manjkata določili o razvrščanju podobno ali enako pisanih iztočnic tipa Jézus :: jézus (torej ko se razlikujeta velika in mala začetnica) ali à la :: àla (ko je v eni od iztočnic presledek) ali o razvrščanju glagolov, ki se razlikujejo od neprve osnovne slovarske oblike dalje (obíti -ídem :: obíti obíjem) - tako so razvrščene iztočnice v SSKJ-ju.

Slovar slovenskih homonimov (Bálint 1997) ima iz SSKJ-ja nabranih veliko besed, ki so problematične za razvrščanje (večinoma gre za enako pisane besede) in zanimive tudi za tukajšnjo obravnavo, vendar seznam ni zanesljiv: če je bila "zaradi besednovrstne značilnosti« (Bálint 1997: 18) opuščena homonimna vrsta plésen ${ }^{1}$ ž 'glivična bolezen' :: plésen $^{2}$ prid. 'nanašajoč se na ples', ni jasno, zakaj je avtorica uvedla nove homonimne vrste mát $\mathrm{m}$ (pri šahu) :: mát prid. 'ki je brez močnega sijaja', pŕst $\mathrm{m}::$ pŕst ž in striči $\mathrm{m}$ 'stric' :: stríči nedov. 'krajšati lase, dlako' ali zakaj ob pót $\mathrm{m}$ 'pot' ž :: pót $\mathrm{m}$ 'sel' $::$ pót $\mathrm{m}$ 'znoj' ni upoštevala tudi pót ž. $\mathrm{V}$ tem slovarju pripisani indeksi le redko izvirajo iz SSKJ-ja.

SP 1962 ima podobno in enako pisane iztočnice razvrščene na različne načine: goríca :: Goríca, hríb :: Hríb, vŕh $\mathrm{m}$ :: Vŕh :: vŕh predl., zèl zlà -ò prid. :: zél -í ž, toda bél -í ž :: bél -a -o, góst -a -o :: gòst gôsta m, lùk medm. :: lúk -a m.

Tudi OSSJ Milene Hajnšek-Holz in Primoža Jakopina ima v uvodu navedena na videz zelo natančna določila za razvrščanje podobno in enako pisanih iztočnic, vendar se jih potem začuda ne drži (OSSJ: VIII; vezaji namesto odstavčnih pomišljajev so že v izvirniku):

》Gesla so razvrščena po abecedi s končne strani. Pri razvrščanju sva upoštevala naslednje:

- absolutna abeceda: a, aa, aba;

- naglasno mesto in kvaliteta samoglasnikov: a, á, à; e, é, è, ê; i, í, ì; o, ó, ò, ô; r, ŕ; u, ú, ù; snubačíca, snubáčica; mézda, mèzda, mêzda;

$-[..] \ll$

Ker so gesla »razvrščena po abecedi s končne strani«, je zaporedje snubačica :: snubáčica napačno, saj bi moral glede na navedeno določilo imeti nenaglašeni $i \mathrm{v}$ snubácica prednost pred naglašenim v snubačica. Izvedba (seveda odzadnja) je sicer v skladu s SSKJ-jem (SSKJ 1: § 8: „Enako pisana gesla iz iste besedne vrste 
so razvrščena: [..] 3. po kvantiteti naglašenega samoglasnika: geslo z dolgim naglasom stoji pred geslom s kratkim naglasom ali brez naglasa (bór : bòr) [..]«) in ni jasno, zakaj jo je OSSJ v navodilih zabrisal. Glede na določila, navedena v OSSJju, je zaporedje mézda :: mèzda :: mêzda ustrezno. (Prim. Weiss 1996/97: 81.) SSKJ je seveda moral biti nadgrajen, saj se v OSSJ-ju srečajo iztočnice in dvojnice k njim ter podiztočnice in dvojnice $\mathrm{k}$ njim. Na nekatere primere pa pisci SSKJ-ja niso bili pozorni, kot je bilo že rečeno (Kristus :: kristus). OSSJ to izrecno popravlja, tako da stojijo $\mathrm{v}$ njem iztočnice $\mathrm{z}$ malo začetnico pred tistimi $\mathrm{z}$ veliko in je torej zanemarjeno neustrezno načelo razvrščanja podobno- in enakopisnic po tvorjenosti, ki je bilo najbrž upoštevano v SSKJ-ju.

In kako ravnajo $v$ takih primerih slovenska enciklopedična (in leksikonska) dela?

ES v uvodu izčrpno in ustrezno navaja pravila, po katerih se razvrščajo gesla, še posebej homonimna (npr. ES 6: XI), le da ni povsem jasno, ali je za iztočnico treba šteti tudi ime ob priimku ali ne; razvrstitev primerov pri KUHAR oz. KÜHAR kaže, da je osebno ime del iztočnice, zaporedje iz uvoda BOJC, Ruža :: BOJCBIDOVEC, Franja pa, da ni (ES 6: XI, 64-65).

LCZ 1994 glede razvrščanja po abecedi in razvrščanja homonimov nima navedenih pravil, ravna pa nerazvidno, saj je zaporedje v njem npr. bill 'listina' :: Bill |švicarski arhitektl (v pokončnicah so moja pojasnila), vendar pa tudi Viktorija lkraljica Velike Britanijel :: Viktorija |avstralska zvezna država| :: viktorija llokvanjl.

VSL ravna pri razvrščanju nasploh malce nejasno in ima v uvodu navedeni dve pravili glede zaporedja, in sicer pri članih družine $z$ enakim priimkom, ki so obravnavani v istem geslu (tu so »bližnji in daljni sorodniki [..] razporejeni po starosti, od najstarejšega do najmlajšega«), vendar pa pod isto iztočnico niso združena enakozvočna osebna in zemljepisna imena, npr. Ǎ̌, Šalom $\mid$ pisatelj| :: Aš $\mid$ mesto na Češkem|. »V takšnem primeru je po abecednem redu na prvem mestu vedno osebno ime, na drugem zemljepisno« (VSL 1: XIII). Očitno je to premalo, saj marsikaj ostane nerazloženo; tako je v samem leksikonu zaporedje npr. AL |Alabama| :: al |arabski določni člen| :: Al laluminijl :: a. l. lad libituml, MRK :: mrk, Mrak :: mrak, MP :: m. p., Mura |rekal :: Mura, d. d. Ipodjetjel :: mura (to zaporedje je toliko bolj nenavadno, ker je dodatek $d$. $d$. 'delniška družba', če sodimo po vrsti tiska, del iztočnice), pH :: ph, Vas :: vas. Velike črke ali več velikih črk imajo prednost pred (več) malimi črkami, vendar vrsta iztočnic od $A L$ do $a$. $l$. ni urejena po tem pravilu.

Tovrstna določila - če so se pisci slovarjev sploh dokopali do njih - so v uvodih k slovarjem nasploh navedena le redko ali pa so zelo kratka. Tako France Verbinc v uvodu k Slovarju tujk piše: »Vsa gesla so urejena po strogem abecednem redu. To velja tudi za kratice, citate in zveze s predlogi. Gesla en face, en gros, in absentia, in causa itd. so torej uvrščena po abecedi tako, kakor bi bili sestavini ena beseda." (Verbinc 1979: 8) Kako težki primeri čakajo slovaropisca, se vidi iz začetka Verbinčevega slovarja (Verbinc 1979: 19):

A lamperl

Å langstreml 
a llatinski predlogl

a litalijanski predlog|

a larl

à |francoski predlog|

A |Annol

a. lannol

a- 'ne..'

a. a. lad actal

To res niso kake velike in usodne stvari. Slovar si prizadeva napraviti red v jeziku (poskuša torej skorajda nemogoče), zato je nerodno, če mu spodleti že pri povsem tehnično obvladljivem. Pri vsakem slovarskem ali enciklopedičnem oz. leksikonskem delu je treba pravila določiti ob samem začetku in se jih potem držati in jih dopolnjevati glede na posebnosti v gradivu. Splošnih pravil zaradi posebnosti posameznih del ne more biti.

\section{C}

Pri urejanju iztočnic za slovarski del novega Slovenskega pravopisa, ki nastaja na Inštitutu za slovenski jezik Frana Ramovša pri Znanstvenoraziskovalnem centru Slovenske akademije znanosti in umetnosti v Ljubljani, so veliki množini besed iz SSKJ-ja dodana še lastna imena, tako da prihaja do srečanj tipa delo :: Delo |časopis| ali drava lcigaretal :: Drava |reka|; istovrstni primeri morajo biti razvrščeni kar se da enako, uporabnik pa jih mora najti na pričakovanih mestih. Pravila morajo biti trdna, tako da jih lahko obvladajo tako sestavljalci kot uporabniki.

Določila, ki so objavljena tule, niso zavezujoča (niti za sestavljalce slovarskega dela Slovenskega pravopisa ne) in jim bo mogoče treba dodati tudi kaj takega, kar se do zdaj še ni pokazalo kot problem. Nanašajo se samo na konkretno slovarsko delo, torej na slovarski del Slovenskega pravopisa, in bodo mogoče morala biti glede na spremembe $v$ gradivu še spremenjena in dopolnjena. Izbrani primeri izvirajo iz pripravljalnih različic pri izdelovanju slovarskega dela Slovenskega pravopisa in iz SSKJ-ja, ponekod pa so skonstruirani.

Gradivo, ki se ponuja v razvrščanje, je pripeljalo do rezultata, kot je predstavljen, ponekod pa pušča še odprte rešitve. Natančno razvrščanje je pomembno tudi zato, ker se ob njem pokaže potreba po dodajanju indeksov pri iztočnicah, ki se ne razlikujejo v pisni podobi, naglasu, besednovrstnem podatku, spolu ali podatku o neprvi osnovni slovarski obliki, indeksi pa olajšajo ali sploh omogočajo rabo kazalk in vodilk ter sopomenk v slovarju (npr. dreti ${ }^{1} \mid$ silovito in hitro teči| :: dreti ${ }^{2}$ |odstranjevati kožo|).

Prvotna pravila za razvrščanje podobno in enako pisanih iztočnic je obravnavala Komisija za sestavo slovarskega dela novega Slovenskega pravopisa, ki ji predseduje akad. prof. dr. Jože Toporišič, in sicer na 85. seji 13. oktobra 1992 ter na 216. in 217. seji 17. decembra 1996 in 15. januarja 1997.

0.0 Nasploh veljajo pri razvrščanju podobno in enako pisanih iztočnic $\mathrm{v}$ slovarskem delu pripravljajočega se Slovenskega pravopisa smiselno prirejena do- 

sledijo takole:

2.1 po besednih vrstah:

(a) (aa) samostalnik, ki se pregiba z glasovnimi končnicami, (ab) samostalnik, ki se ne pregiba z glasovnimi končnicami (prim. točko 2.1.1);

(b) samostalniški zaimek;

(c) (ca) pridevnik, ki se pregiba z glasovnimi končnicami, (cb) pridevnik, ki se ne pregiba z glasovnimi končnicami (prim. točko 2.1.1);

(ॅ) števnik;

(d) pridevniški zaimek;

(e) glagol;

(f) prislov;

(g) povedkovnik (prim. točko 2.1.2);

(h) predlog;

(i) veznik;

(j) medmet;

(k) členek; 
ima prednost pred tisto z zgolj neglasovno (B -- in B-ja :: B --); to določilo sicer ni dosledno, saj nasprotuje tistemu v točki 3.6, vendar pa nam pri posameznih črkah edino lahko zadrži imena črk na prvih mestih;

2.1.2 povedkovniki so večinoma nepregibni (in tvorjeni iz prislova), včasih pa se vendarle pregibajo (npr. $r a d-a-o$ ); glede na to bi moralo biti mesto povedkovnika pravzaprav med glagolom in prislovom;

2.2 besednovrstno ne natančneje opredeljene iztočnice:

(a) prosti morfemi ipd. (se); 'umrl');

(b) krajšave (e. c. 'exempli causa', est. 'estonsko, estonščina', o. 'oče', u.

2.3 orientacijske iztočnice (v zvezi z besedotvorjem):

(a) predpona v sestavljenkah (hipo.., o..., u..);

(b) prvi del podrednih zloženk (belo.., hipo.., backhand);

(c) prvi del prirednih zloženk (belo-);

(c) medpona (..o...);

(d) drugi del prirednih zloženk (..basen, ..bus, ..tonski);

(e) priponsko obrazilo (..aš, ..ast, ..ec, ..est); če bi bilo enako pisanih priponskih obrazil več, si sledijo, kot izhaja iz točk 2.1 in 3.1-3.7;

2.3.1 enako pisani enakovrstni prvi deli zloženk se razvrščajo po nadaljnjih pravilih (bákro.. :: bakro..; prim. točke 3.3-3.5 in 4.4);

2.4 kazalke (baklja, bil loblika glagola biti seml).

3.0 Enako ali podobno pisane iztočnice iz iste besedne vrste (točka 2.1) ali enako ali podobno pisane orientacijske iztočnice (točka 2.3) so razvrščene:

3.1 po spolu: moški spol ima prednost pred ženskim in srednjim, ženski pred srednjim (brst $\mathrm{m}::$ brst $\check{z}$ );

3.2 po glagolskem vidu: dovršni ali nedovršni glagol ima prednost pred dvovidskim (dotirati dov. :: dotirati dvovid.);

3.3 po mestu naglasa: iztočnica $\mathrm{z}$ naglasom na prvem zlogu stoji pred iztočnico z naglasom na drugih zlogih (blagôvnica :: blagovníca, àtóničen :: atóničen);

3.3.1 iztočnica $\mathrm{z}$ nepremičnim naglasnim tipom ima prednost pred tisto $\mathrm{s}$ premičnim, končniškim ali mešanim (Jádran -a m, oseb. i. :: Jádran -ána 'Jadransko morje'), dúh -a :: dúh -á);

3.4 po kolikosti naglašenega samoglasnika:

(a) iztočnica $z$ dolgim naglasom stoji pred iztočnico s kratkim naglasom ali brez njega (bór :: bòr, Húgo :: Hugo [igó]);

(b) iztočnica $\mathrm{z}$ dolgim naglasom $\mathrm{v}$ izgovoru $\mathrm{v}$ oglatih oklepajih ima prednost pred tisto s (samo) kratkim naglasom ali brez njega (back.. [bék] :: back.. [bèk]);

3.5 po kakovosti naglašenega samoglasnika:

(a) iztočnica z ozkim samoglasnikom stoji pred iztočnico s širokim samoglasnikom (bébav :: bêbav);

(b) iztočnica $\mathrm{z}$ ozkim samoglasnikom v izgovoru $\mathrm{v}$ oglatih oklepajih stoji pred tisto $\mathrm{s}$ širokim samoglasnikom; 
3.6 po tem, ali je iztočnica brez dvojnice ali z dvojnico (bisus -a :: bisus -a ... tudi bis -a); ponekod je dvojnica navedena za podpičjem na koncu gesla za oznakama in ali tudi; toda prim. omejitev v točki 2.1.1;

3.7 od tod dalje navedenih določil ni v SSKJ-ju:

3.7.1 iztočnica brez posebnega izgovora stoji pred tisto s posebnim izgovorom v oglatih oklepajih (blodilka :: blodilka [ụk]); različne omejitve izgovora tipa in in tudi ne vplivajo na razvrstitev enakopisnic;

3.7.2 nezaznamovana iztočnica ima prednost pred zaznamovano (božica ubožica :: božica star. boginja); zaznamovanost se šteje v zaporedju (a) socialnozvrstno, (b) funkcijskozvrstno, (c) splošno normativno, (č) čustvenostno, (d) časovno, (e) pogostnostno, (f) izrazijsko (npr. drgalka zastar. :: drgalka agr.);

3.7.3 samostalniška iztočnica, ki se ji osnova $v$ rodilniku ne podaljšuje, ima prednost pred tisto, ki se ji (drevče -a s :: drevče -ta s);

3.7.4 pri samostalniški iztočnici ima »čisti« samostalnik prednost pred samostalnikom z dodatkom, da gre za simbol (B -- $\mathrm{m}::$ B -- m, simb.); geslo z golim besednovrstnim podatkom ima nasploh prednost pred geslom $\mathrm{s}$ takim podatkom $\mathrm{z}$ dodatkom (srčno prisl. :: srčno nač. prisl.);

3.7.5 pri samostalniku moškega spola ima iztočnica $\mathrm{z}$ golim podatkom $\mathrm{m}$ (za golega se šteje tudi podatek $\mathrm{m} z$ dodatki pojm., skup., števn.) prednost pred tistim $\mathrm{s}$ podatkom m živ. (ta ima pač bolj zapleten sklanjatveni vzorec) ali takim, ki to oznako skriva, npr. m, oseb. i. ali m člov. (kuli m |kemični svinčnik| :: kuli m živ. Inekvalificirani delavec (v Aziji)l);

3.7.6 pri pridevniku ima iztočnica brez neobstojnega glasu prednost pred tisto z neobstojnim glasom, večinoma polglasnikom (določen -a -o :: določen -čna $-0)$;

3.7.7 pri pridevniku ima geslo brez zapisane oblike primernika (ki se torej (lahko) stopnjuje s prislovom bolj) prednost pred tisto $\mathrm{z}$ navedenim primernikom (bučen -čna -o :: bučen -čna -o, -ejši -a -e);

3.7.8 pri lastnih imenih si dodatki sledijo v zaporedju (a) stvarno ime, (b) zemljepisno ime, (c) osebno ime, saj ima osebno ime pri moškem spolu zaradi sicer nezapisanega podatka o podspolu živosti (živ.) bolj zapleten sklanjatveni vzorec (Kos stvar. i. :: Kos oseb. i.; Lev astr. i. :: Lev oseb. i.; Amazonka zem. i. :: Amazonka oseb. i.; Kočevar preb. i. :: Kočevar oseb. i.);

3.7.9 pri zemljepisnih imenih ima prednost geslo, ki vsebuje manj izpeljank (Pesnica |rekal :: Pesnica $\mid \mathrm{krajl})$;

3.7.10 pri enako pisanih imenih enakovrstnih zemljepisnih danosti (kraj, reka ...) ima prednost tista, ki je prostorsko bližja (Tržič lv Slovenijil :: Tržič lv Italijil);

3.7.11 pri slovenskih krajevnih imenih, pri katerih so enaki vsi podatki do (izključno) tonemskega naglasa, si gesla sledijo po abecednem zaporedju pripisanih imen občin, ki so navedena v pokončnicah (Brode |o. Braslovče| :: Brode lo. Škofja Lokal);

3.7.12 pri enako pisanih simbolih iz različnih strok si iztočnice sledijo po abecednem zaporedju označevalnikov (Pa fiz. :: Pa kem.);

3.7.13 pri enako pisanih glagolih ima prednost geslo, $v$ katerem ima neprva 
osnovna slovarska oblika:

(a) samoglasnik, ki je nepremenjen ali glasovno bližji samoglasniku v nedoločniku (obstáti -stánem :: obstáti -stojím, napéti -pôjem :: napéti -pnèm, bíti bíjem :: bíti sèm, napásti -pásem :: napásti -pádem);

(b) krajšo predpono (obrísati obríšem :: obrísati -ríšem);

3.7.13.1 v težavnejših primerih se je najbolje opreti na rešitve v SSKJ-ju;

3.7.14 pri iztočnicah, ki jih ni mogoče razvrstiti po navedenih pravilih, se upošteva možna pomenska uvrstitev, in sicer po zaporedju, ki izhaja iz točke 2.1 (blago.. |blago sl :: blago.. Iblag prid.l, B -- [bə̀ in bé] $\mathrm{m}$ Belgija :: B -- [bò in bé] $\mathrm{m}$ blok $18 \mathrm{~B})$.

4.0 Iztočnice, tudi tiste, katerih sestavina je vsaj en presledek, eno ločilo ali dodatno znamenje (brez njega ali njih bi se dve iztočnici pisali enako), se - potem ko so upoštevana in izčrpana že navedena določila - razvrščajo takole:

4.1 enobesedna iztočnica, tudi taka $\mathrm{z}$ ločili med posameznimi sestavinami, ima prednost pred tako $\mathrm{z}$ ločilom med sestavinami ali pred dvo- ali večbesedno (nasvidenje :: na svidenje, bledomoder :: bledo-moder :: bledo moder);

4.1.1 gola, zgolj črkovna iztočnica ima prednost pred tisto, ki ima (tudi notranje) ločilo (samo teoretično: ti :: ti. :: t.i 1.1 :: t.i. :: t.-i. :: t $\mathbf{i}::$ t. i.); šele nato (prim. točke 2.2-2.4) so zapisane morebitne orientacijske iztočnice; iztočnice z ločili si torej sledijo takole: pika, stični dve piki, vezaj, pomišljaj (če bi kje nastopila taka zadrega po upoštevanju vseh dosedanjih določil);

$4.2 \mathrm{z}$ navadnimi črkami ali številkami zapisana iztočnica ima prednost pred sicer podobno zapisano iztočnico z nad- ali podpisano črko ali števko oz. nad- ali podpisanimi črkami ali števkami (Cie :: Cie);

4.3 gola iztočnica ima prednost pred iztočnico z (a) nad- ali (b) podpisano števko, tiste s števkami pa si sledijo po naraščajoči številski velikosti $\left(\mathbf{c m}:: \mathbf{c m}^{2}::\right.$ (teoretično) $\mathbf{c m}^{13}$ );

4.3.1 nadpisane črke ali števke je treba ločiti od drugih znamenj, ki se razvrščajo za podobno pisane gole iztočnice, torej za podobno pisane iztočnice brez ločil in znamenj (npr. nadpisani $o$ v primeru fo 'folio' - ta se razvršča, kot da bi bil fo) od stopinje v primeru ${ }^{\circ} \mathbf{F}$ 'stopinja Fahrenheita');

4.4 nemški $\beta$ stoji za črkama ss, ligatura $\alpha$ sledi črkama $a e$ in ligatura $\alpha$ sledi črkama oe (Gross :: Groß);

4.5 turški $\imath$ stoji za slovensko črko $i$ in turški $I$ za slovensko črko $I$, s katerima sta sicer položajno izenačena;

4.6 islandski $\partial$ stoji za črko $d$, islandski $p$ pa za črko $t$, s katerima sta sicer položajno izenačena;

4.7 latiničnim črkam podobni simboli za valute stojijo (če so sploh uvrščeni v slovarski del) na koncu z veliko pisanih latiničnih črk kot iztočnic, npr. $€$ (simbol za evro) za $\mathbf{E}, \mathbf{L}$ (simbol za funt) za $\mathbf{L}, \$$ (simbol za dolar) za $\mathbf{S}$ in $¥$ (simbol za jen) za $\mathbf{Y}$; te simbole je sicer bolje predstaviti v posebni preglednici;

4.8 male grške črke stojijo (če so sploh uvrščene v slovarski del) na koncu malih latiničnih črk kot iztočnic ( $\beta$ torej pride med b in b-); velike grške črke stojijo na koncu velikih latiničnih črk kot iztočnic za latiničnim črkam podobnimi simboli 
(I torej pride za P); nekatere grške črke se v slovenščini namreč razvežejo v dve črki, zato je njihovo uvrščanje v slovarski del lahko zelo sporno; če so že uvrščene, je zaporedje samih grških črk tákole (velja tudi za velike): $\delta$ in s kazalko $\zeta(\zeta$ sicer za $z), \tau$ in s kazalko $\boldsymbol{\theta}(\boldsymbol{\theta}$ sicer za th), $\boldsymbol{\kappa}$ in s kazalko $\xi(\xi$ sicer za $\mathbf{x}), \boldsymbol{\pi}$ in s kazalko $\psi$ ( $\boldsymbol{\psi}$ sicer za ps), $\varepsilon$ in $\eta, \boldsymbol{o}$ in $\boldsymbol{\omega}$; te črke je sicer priporočljivo predstaviti v posebni preglednici, kar je v SP 1997: § 1107 z drugimi nameni že storjeno.

\subsection{Indeksi}

5.1 Ponekod so pri enakopisnicah uvedeni indeksi (nadpisane številke), npr. enkrátnost ${ }^{1}$ in enkrátnost ${ }^{2}$, ki pri sklicevanjih pomagajo $\mathrm{k}$ bolj natančni določitvi iztočnice, na katero se kaže. Indeksi se ne pišejo, če je razlika med dvema ali več podobno- ali enakopisnicami:

(a) v pisni podobi iztočnice (drava |cigaretal :: Drava |rekal);

(b) v naglasu (ênoglásen :: enoglásen);

(c) $\mathrm{v}$ besednovrstnem podatku (jaz zaim. :: jaz m);

(č) $\mathrm{v}$ spolu (prst $\mathrm{m}::$ prst $\check{z}$ );

(d) v podatku o neprvi osnovni slovarski obliki (določen -a -o :: določen -čna -o, drevče -a :: drevče -ta), ki lahko vsebuje naglasni podatek (dúh -a :: dúh -á).

5.1.1 Indeks je pripisan, če eni od iztočnic sledi naglasna dvojica (cépati -am :: cépati -am tudi cépati -am; gúmar lvozl :: gúmar tudi gumár |delavecl).

5.1.2 Nadaljnje razvrščanje indeksiranih iztočnic naj bo pri različnih predponah (a) po možnosti enako glede na osnovo, (b) zaznamovane iztočnice pa si sledijo, kot je navedeno v točki 3.7.2.

5.2 Razlikovalne sestavine - in tudi indeksi - se pišejo pri morebitnih kazalkah in vodilkah, ki kažejo na enako pisane iztočnice, ter pri sopomenkah. Indekse je smiselno dokončno pripisati in pregledati v eni od zadnjih faz dela, vmes pa jih ni dobro navajati, saj njihove spremembe lahko med delom povzročijo zmedo in škodo.

\section{Navedenke}

AS 1985 = Atlas Slovenije, Ljubljana: Mladinska knjiga - Geodetski zavod SR Slovenije, 1985.

BÁLINT 1997 = Júlia Bálint, Slovar slovenskih homonimov: Na podlagi gesel Slovarja slovenskega knjižnega jezika, Ljubljana: Znanstveni inštitut Filozofske fakultete, 1997 (Razprave Filozofske fakultete).

ES 6 = Enciklopedija Slovenije 6: Krek-Marij, Ljubljana: Mladinska knjiga, 1992. ES $8=$ Enciklopedija Slovenije 8: Nos-Pli, Ljubljana: Mladinska knjiga, 1994.

KARNIČAR 1999 = Ludvik Karničar (ur.), Deutsch-windisches Wörterbuch mit einer Sammlung der verdeutschten windischen Stammwörter, und einiger vorzüglichern abstammenden Wörter von Oswald Gutsmann, Klagenfurt 1789: Auf Slowenisch-Deutsch umgekehrt und bearbeitet von Ludwig Karničar, Graz: Institut für Slawistik der Universität Graz, 1999 (Slowenistische Forschungsberichte 3). 
KENDA-JEŽ - WEISS 1999 = Karmen Kenda-Jež - Peter Weiss, Posebnosti (slovenskega) narečnega slovaropisja, v: Seminar slovenskega jezika, literature in kulture: Zbornik predavanj 35, Ljubljana: Filozofska fakulteta, 1999, str. 27-46.

KOBLISCHKE 1983 = Heinz Koblischke, Großes Abkürzungsbuch: Abkürzungen - Kurzwörter-Zeichen -Symbole, Leipzig: Bibliographisches Institut, ${ }^{3} 1983$.

KOŠIR 1997 = Stanko Košir, B 's'dnjak rutaršćê 'n srenšćê šprašê (Slovar rutarške in srenške govorice), Rute [= Gozd Martuljek]: samozaložba, 1997.

KUZNJECOVA - JEFREMOVA 1986 = A. I. Kuznecova - T. F. Efremova, Slovar' morfem russkogo jazyka, Moskva: Russkij jazyk, 1986.

LANDAU 1991 = Sidney I. Landau, Dictionaries: The Art and Craft of Lexicography, Cambridge idr.: CUP, 1991.

LCZ = Leksikon Cankarjeve založbe, Ljubljana: Cankarjeva založba, ${ }^{3} 1994$.

LONGMAN 1992 = Longman Dictionary of English Language and Culture, Essex: Longman, 1992.

Metzler Lexikon Sprache 1993 = Metzler Lexikon Sprache (ur. Helmut Glück), Stuttgart - Weimar: J. B. Metzler, 1993.

MUREN 1989 = Hinko Muren, Priročnik STEVE: Urejevalnik besedil, slik in podatkovnih zbirk, Ljubljana: Fakulteta za strojništvo, 1989.

Nemško-slovenski slikovni slovar 1987 = Oxford - Duden - Cankarjeva založba: Nemško-slovenski slikovni slovar, Mannheim: Bibliographisches Institut Ljubljana: Cankarjeva založba, 1987.

NOVAK 1988 = Vilko Novak, Slovar stare knjižne prekmurščine: Poskusni snopič, Ljubljana: ZRC SAZU, 1988.

NOVAK 1996 = Franc Novak, Slovar beltinskega prekmurskega govora, Drugo, popravljeno in dopolnjeno izdajo priredil in uredil Vilko Novak, Murska Sobota: Prekmurska založba, 1996.

OSSJ = Milena Hajnšek-Holz - Primož Jakopin, Odzadnji slovar slovenskega jezika po Slovarju slovenskega knjižnega jezika, Ljubljana: ZRC SAZU - SAZU, 1996 (Slovarji).

PARNWELL 1986 = Eric Charles Parnwell, Oxford English Picture Dictionary: Angleško-slovenski slikovni slovar, Oxford: Oxford University Press - Ljubljana: Cankarjeva založba, 1986.

SP 1997 = Slovenski pravopis 1: Pravila - Peta, ponovno pregledana izdaja, Ljubljana: SAZU (izd.) - DZS (zal.), 1997.

SSKJ = Slovar slovenskega knjižnega jezika 1-5, Ljubljana: SAZU oz. ZRC SAZU (izd.) - DZS (zal.), 1970-1991.

SVENSÉN 1993 = Bo Svensén, Practical Lexicography: Principles and Methods of Dictionary-Making, Oxford - New York: OUP, 1993.

Svetovna književnost 1984 = Svetovna književnost, Ljubljana: Cankarjeva založba, 1984 (Leksikoni Cankarjeve založbe).

TIS 19981 = Telefonski imenik Slovenije 1998 1: Ljubljana, Trbovlje, Ljubljana: Telekom Slovenije, 1998.

TIS 2000 = Telefonski imenik Slovenije 2000: Ljubljana, Trbovlje, Ljubljana: Telekom Slovenije, 1999. 
- TOPORIŠIČ 1994 = Jože Toporišič, Teoretična podstava novega slovarja SP, Slavistična revija 42 (1994), št. 4, str. 455-473.

Turistična avtokarta Slovenije $1999=$ Turistična avtokarta Slovenije $(1: 270.000)$, Ljubljana: Avto-moto zveza Slovenije, 1999.

VERBINC $1979=$ France Verbinc, Slovar tujk, Ljubljana: Cankarjeva založba, ${ }^{6} 1979$. VSL 1-8 = Veliki splošni leksikon 1-8, Ljubljana: DZS, 1997-98.

WEBSTER 1980 = Webster's New Collegiate Dictionary, Springfield, Mass.: G. \& C. Merriam Company, 1980.

WEISS 1996/97 = Peter Weiss, Odzadnji slovar, dve gospe in en stavek, Slava: Debatni list 10 (1996/97), št. 1, str. 65-86.

WEISS 1998 = Peter Weiss, Slovar govorov Zadrečke doline med Gornjim Gradom in Nazarjami: Poskusni zvezek (A-H), Ljubljana: ZRC SAZU, 1998 (Slovarji).

WEISS 1998a = Peter Weiss, Trije narečni slovarji, v: Jezikoslovni zapiski 4 (1998), str. 189-196.

WEISS 1999 = Peter Weiss, Slovnični podatki v Murkovem slovensko-nemškem slovarju, v: Murkov zbornik: Referati s simpozija Anton Murko in njegov čas, Maribor: Slavistično društvo Maribor (Zora 9), str. 204-224.

WEISS $1999 \mathrm{a}=$ Peter Weiss, Iz nemško-slovenskega slovarja po 210 letih še slovensko-nemški, Delo - Književni listi 1999 (23. sept.), str. 21.

WEISS $1999 \mathrm{~b}=$ Peter Weiss, Skoraj vsi tatovi so notri, a kaj ko jih ne bodo našli niti kompanjoni ..., Delo - Znanost 1999 (6. okt.), str. 16.

WIEGAND 1989 = Herbert Ernst Wiegand, Aspekte der Makrostruktur im allgemeinen einsprachigen Wörterbuch: alphabetische Anordnungsformen und ihre Probleme, v: Wörterbücher-Dictionaries - Dictionnaires: Ein internationales Handbuch zur Lexikographie 1, Berlin - New York: Walter de Gruyter, 1989 (Handbuch zur Sprach- und Kommunikationswissenschaft 5.1), str. 371-409.

ZGUSTA 1991 = Ladislav Zgusta, Priručnik leksikografije, Sarajevo: Svjetlost, 1991. 


\section{Guidelines for Ordering of Main Entries Having Similar or Homonymous Spellings in the Dictionary Part of the New Slovenian Orthographic Code}

Summary

The principles which Slovenian dictionaries and encyclopedias (lexicons) use in alphabetization and ordering of main entries having similar or homonymous spellings are discussed in the first part of the article. For the dictionary part of the new Slovenian Orthographic Code guidelines are suggested for uniform ordering of main entries with similar or homonymous spelling (e.g. iskra and Iskra, o and o. and ..o.. and $0 . .$, prst $-a$ : prst $-i$, določen - $a$-o and določen -čn $a-o$, biti bijem and biti sem), and the use of index numbers for main entries sharing equal features such as spelling, stress, information on word class, gender and the first inflected form to be included in the dictionary. Lexicographers should pay more attention to this stage in preparation of a dictionary or an encyclopedia, since the users tend to distrust any work that fails to list the main entries according to given principles. 